\title{
The Pegida Movement and German Political Culture: Is Right-Wing Populism Here to Stay?
}

JÖRG MICHAEL DOSTAL

\begin{abstract}
This article outlines the rise and fall of the 'Patriotic Europeans against the Islamisation of the West' (Pegida), a right-wing populist street movement that originated in the city of Dresden in October 2014 and peaked in January 2015. The Pegida movement combined fear of 'Islamisation' with general criticism of Germany's political class and the mainstream media. This ambivalent and largely undefined political profile proved its strength in mobilising a significant minority of right-wing citizens in the local context of Dresden and the federal state of Saxony, but generally failed to spill over to other parts of Germany. The social profile of the Pegida movement, which included 'ordinary citizens' with centre-right to far-right attitudes, points to significant overlap between general disenchantment of the political centre ground in Germany with the political system, as outlined in recent sociological research, and the ability of a largely leaderless populism to mobilise in the streets.
\end{abstract}

Keywords: Dresden, German politics, middle class, milieu theory, Pegida, populism

\section{Introduction}

BETWEEN late October 2014 and mid-January 2015, political debate in Germany was captured by the rapid emergence of a new political movement, namely the so-called 'Patriotic Europeans against the Islamisation of the West' (abbreviated to Pegida in German, with 'A' standing for 'Abendland' or Occident in the German original). What was most remarkable about the Pegida movement was its emergence from the collaboration of around a dozen citizens without any earlier exposure to professional politics (only three of the twelve had previous contacts with political parties at the local level, with one each in the Christian Democrats (CDU), the Free Democrats (FDP) and the anti-Euro 'Alternative for Germany' (AfD) party). The citizen activists all live in or close to the German town of Dresden in the East German state of Saxony. This federal state has, since the 1990s, always been governed by the centre-right CDU with an absolute majority or in coalition with the Social Democrats (SPD) (2004-09 and since 2014) and FDP (2009-14) in the regional parliament, which is also located in Dresden, the state's capital.
In order to understand the Pegida phenomenon, one must first highlight the dominance of conservative politics in Saxony. This state's political system includes three parties that compete with the governing $\mathrm{CDU}$ on the right, namely the market-liberal Free Democrats (FDP); the AfD, a new rightwing political force that was founded in 2013 and has some similarities with UKIP in Britain; and the far-right and extremist National Democrats (NPD). Although the FDP and the NPD lost their representation in the regional parliament in the latest 2014 election, the overall right-wing share of the electorate is probably higher in Saxony than in any other German state. On the left, the major opposition force in Saxony is Die Linke, the Left Party, formed from a merger of the remnants of East German socialism and West German leftists who split from the SPD when it moved rightward in the 2000s. The SPD itself, currently junior partner of the federal government in Berlin, is very weak in Saxony.

The group of citizens that founded Pegida was notable for criticising the Christian Democrats and the entire political spectrum in Germany from positions mostly associated 
with right-wing ideology - the movement insisted on representing 'ordinary' people and suggested that 'true' conservatism was represented by Pegida rather than the Merkel-CDU. In short, the Pegida supporters claimed to defend the mainstream of German culture and traditions against a liberal elite and political establishment that was alienated from its own people.

To the surprise of practically everyone, Pegida founders included, the movement quickly took off and proved able to mobilise large numbers of citizens to participate in street rallies: the number of participants in weekly manifestations in Dresden (held every Monday to copy the tradition of the mass mobilisations that brought down the East German state, the GDR, in 1989) expanded from 350 on 20 October 2014 (the day of the first rally) to up to 25,000 on 12 January 2015, when the movement peaked. Soon after, the level of participation in the Dresden rallies declined nearly as quickly as it had grown beforehand. This rapid decline appeared to suggest that Pegida had over-expanded, suffered from internal contradictions and could possibly disappear as quickly as it had come into existence.

This article offers an analysis of the Pegida phenomenon, suggesting that the new streetassertive right-wing populism is likely to remain a factor to be reckoned with in German political culture. It is argued that the movement itself might be transient, but that the recent right-wing populism questions the ability of the centre-right parties to integrate different streams of conservatism. Moreover, many German citizens lack confidence in the ability of the political system to secure future prosperity and large sections of the middle class are overwhelmed by socio-economic and cultural change. They fear that largescale migration might further decrease their prospects and social status. In this context, the focus on 'Islamisation' must be read as the symbolic expression of a larger crisis in German politics.

\section{Origins of the Pegida movement}

According to the main founder of the Pegida movement, 42-year-old Lutz Bachmann, the initial reason for calls to mobilise against
'Islamisation' in Germany was his observation of a rally of supporters of the Kurdish Workers' Party (PKK) - outlawed in Germany since 1993 - in the city centre of Dresden in early October 2014. The Kurdish activists demanded solidarity with the citizens of Kobane, a city in Syria then under attack from the 'Islamic State' (ISIS) terrorist organisation. According to Bachmann, political rallies of outlawed foreign political organisations pointed to the danger of 'religious wars' on German streets, a subject that became one of the main mobilising themes of Pegida.

In reaction to his observation of the Kurdish activists, Bachmann and a circle of his friends associated with the local football and party scene founded a Facebook page that has ever since been the major mobilising device of Pegida. From the start-and pointing to the background of some of the Pegida founders, including Bachmann, in public relations - the movement adapted as its symbol a pictogram of a person dropping four political symbols into a rubbish bin. These included the Nazi symbol of the Swastika; the symbol of 'Antifascist Action', which was initially invented by the German Communist Party in the late 1920s; and the two contemporary symbols of ISIS and the Kurdish PKK. ${ }^{1}$

The key dates in the rise of Pegida were as follows: (1) a Facebook page was put up on 11 October 2014; (2) the first rally against 'Islamisation' took place in Dresden, with 350 participants, on 20 October; (3) the number of participants in the Dresden rally grew continuously week by week to up to 25,000 participants on 12 January 2015 (some critical observers believed that the police of Saxony overestimated the figures); (4) since the beginning of December 2014, Pegida-style rallies started to take place across Germany, but the number of participants was generally small - only in Munich, Suhl, Leipzig and Dippoldiswalde did the number of participants rise above 1000, and these rallies all fizzled out quickly.

Overall, Pegida remained a Dresden and Saxony-based phenomenon, with some pockets of support elsewhere, but without a German-wide support base. Moreover, counter-rallies stressing solidarity with minorities soon took off almost everywhere, with these 
rallies clearly outnumbering the Pegida support base in practically all cities other than Dresden. $^{2}$

\section{Pegida's political profile}

In terms of political demands, the Pegida founders initially followed a strategy of calculated ambiguity. There was no list of demands and contact with the mainstream media was avoided, since the Pegida founders argued that the media generally lied to the public (Lügenpresse). Thus, Pegida supporters were advised not to talk to the media. In December 2014, a list of nineteen demands was put forward by the steering committee of the Dresden rallies that included the following: defence of the 'Christian-Jewish culture of the Occident'; a controlled migration policy based on a points system in line with Swiss and Canadian examples; a much quicker system of decision-making on political asylum, followed by the expulsion of all rejected asylum seekers from Germany; more spending on the police and the introduction of popular referenda in line with the Swiss example. ${ }^{3}$ It was noticeable that direct criticism of Islam was carefully avoided. Instead, the rise of 'parallel societies' was criticised as offending against German laws and civil liberties. The nineteen-point, single-page programme was clearly intended to appeal to mainstream conservatives, and could be utilised to avoid criticism of the movement as extremist.

Looking back, the period of ambiguity and avoidance of the media worked well in terms of expanding the movement's appeal. The mainstream media overreacted to the Pegida claim that it was lying by claiming that this directly pointed to similar Nazi slogans against the democratic media. The term 'lying press', a single noun in German, was declared the 'ugliest word of the year 2014' by a society for the protection of the German language. Many journalists seemed to be personally offended by the polemical discourse of Pegida. This triggered, in turn, malicious joy on the part of those who criticised the mainstream media for reasons that differed from Pegida's, and were frequently well founded. ${ }^{4}$

In fact, not talking to the media resulted in the week-by-week dominance of Pegida debates in the media, between those who argued that one should avoid discussion with supporters due to their lack of valid arguments and those who stressed that the degree of support-at least at the local level in Dresden-pointed to the need for democrats to engage with them. Politicians of all parliamentary parties were divided concerning how to react to Pegida: many local and national politicians, including the SPD leader and Vice Chancellor Sigmar Gabriel, favoured engagement and visited a Dresden rally 'as private citizens' to observe the scene.

Until the end of 2014, Pegida's ambiguity allowed integrating all kinds of criticism of real and imagined German problems into the street rallies. The general tone during the Monday rallies was much more radical than the nineteen-point paper. Moreover, visiting speakers raised new topics that did not feature in the nineteen points - such as criticism of the German mainstream media regarding 'anti-Russian' bias in the coverage of events in Ukraine and other issues not related to 'Islamisation'.

Some participants in the Pegida rallies showed wit: slogans such as 'Putin, help us!' were partially ironic, hinting at the rallies of autumn 1989. At that time, East German demonstrators had called for help from then Soviet leader Mikhail Gorbachev in efforts to remove the GDR leadership of Erich Honecker from power. Moreover, news items at the end of 2014-such as the revelation of US intelligence agencies' spying on the German political class-were easy to integrate into Pegida's anti-establishment discourse.

\section{Pegida's decline and split}

In January 2015, the tide started to turn against Pegida. First, the movement abandoned its media boycott and the stage manager and public face of the Dresden rallies, 37-year-old Kathrin Oertel, was duly invited to appear on one of the popular German TV talk shows. On 21 January, the main initiator of Pegida, Lutz Bachmann, made global headlines after the apparent publication of a 'Hitler selfie', according to a German tabloid. The publication of the picture, soon followed by online racist statements by Bachmann 
dating from before his role in Pegida, appeared to prove the movement's extremism. The story gained additional twists due to Bachmann's claim that the picture had been digitally manipulated and the 'Hitler moustache' added. Crucially, he was not able to deny that the racist statements which circulated on the internet were his, although he insisted that he had only 'let off steam' and was being represented in a 'falsified' manner and 'out of context'.

The farce of the Bachmann affair-raising questions about what should be considered 'authentic' in the context of rapidly moving online media-produced a subsequent split within Pegida's leadership body between Bachmann supporters and Kathrin Oertel. The latter resigned from Pegida, stating that the leadership had not distanced itself clearly from more radical rallies elsewhere, such as the so-called Legida, a Leipzig-based alliance with a clear-cut influence of the far right. She soon founded a new group, 'Direct Democracy for Europe'. However, this new association soon fizzled out after only two poorly attended public rallies. Next, she switched to a group named '193 Peace Doves', supposed to represent the states on earth.

Her discourse shifted from her earlier focus on 'conservatism' to new issues that were more in tune with the anti-globalisation movement. Subsequently, Oertel attended various rallies that were linked with criticism of US foreign policy, but her apparent political turnaround-which included a public apology to Muslims for what she referred to as a 'hate campaign' - did not trigger any larger split within Pegida ranks. Instead, Bachmann quickly made a comeback and was re-elected by his peers as a member of the Pegida steering group.

After Bachmann's return, attendance at Pegida's Dresden rallies continued to decline, although the Charlie Hebdo attack in Paris produced brief upturns, as did the invitation to the Dutch right-wing populist politician Geert Wilders to attend as a guest speaker. The so far final political initiative of Bachmann was to recruit Tatjana Festerling, a former AfD party member from the West German city of Hamburg, to put herself forward as a Pegida-backed candidate in the Dresden mayoral elections on 7 June 2015.
Her election result of around 21,000 votes, or nearly 10 per cent, in the context of a low turnout of only 51 per cent signified neither success nor failure.

Before the election, opinion polls had suggested that levels of support for Festerling were much lower, which the movement interpreted as another example of media manipulation. Yet the candidacy also proved that Pegida could not claim to speak for 'the people', but only for a small minority. Only about half of the inhabitants of Dresden cast their vote, and among those, Pegida supporters were outnumbered by a factor of 9 to 1 . In addition, the low turnout underlined the fact that many voters were disconnected, yet dissatisfied for reasons other than those raised by Pegida. Thus, Festerling's decision to withdraw her candidacy in the second round and to support the centre-right FDP candidate-who won the second round against a centre-left candidate-appeared as an effort to re-join the camp of mainstream conservatism, rather than as a sign of Pegida's political strength.

It would be wrong, however, to assume that the Pegida phenomenon has run its course. It must be stressed that the mobilisation was clearly based on right-wing discourses and Pegida leaders frequently stressed that they located themselves to the right of the CDU. One could perhaps go so far to consider Pegida as a kind of prototypical völkisch (ethnic nationalist) movement. Yet this alone cannot explain its initial success, which was due to efforts to put forward demands that were shared by many ordinary citizens. This concerned criticism of the political class for its distance from ordinary people and the voicing of concern about the ongoing refugee crisis in Germany, which derived in turn from the break-up of states in the Middle East and the failure of the European Union to act on this challenge.

Yet one must also highlight that Pegida ultimately failed to appeal to the German public at large. Although successful in the regional context of Dresden and some other places, the movement never developed elsewhere. In short, citizens took note of Pegida and then moved on. There is also no evidence that Pegida mobilised formerly passive milieus to engage in political activism for the first time. Rather, a pre-existing local 
rightist political milieu took to the streets, but remained isolated from the mainstream.

\section{German political culture and Pegida}

It still remains necessary to consider Pegida supporters' claims that they represent the centre (the Mitte) of German society. The second, more analytical part of this article will therefore address the question of the extent to which the Pegida movement points to the receptiveness of Germany's political centre for right-wing populist discourses. This naturally raises additional questions concerning what is actually known about the political centre and its relationship with other sections of society. In fact, analysis might suffer from the very indeterminate character of what is considered to be located 'in the middle'. There exists an economic middle class, usually defined to include those earning between 80 and 150 per cent of the median income. However, political attitudes, lifestyle and other non-economic factors must also be considered to understand what constitutes today's German political centre.

On the one hand, Seymour Martin Lipset warned of potential 'middle-class extremism' in pointing, among other examples, to many middle-class Germans' support for the historical Nazi movement. This thesis has also featured prominently in Marxist accounts referred to by Lipset, stressing that the petty bourgeoisie might turn to the far right during periods of economic crisis, when their relative privileges in comparison with the working class are under threat. ${ }^{6}$

On the other hand, the literature on welfare state capitalism has argued that the middle class has become the backbone of a political coalition supporting policies of inclusive social solidarity. It is argued that the modern welfare state remains highly popular with the middle class and continues to protect the centre of society against social risks. Slightly less optimistic, yet still within the theme of solidarity of the middle classes, is the more recent idea that economic restructuring and socio-economic change have made the middle class aware that reliance on individual effort and resources is no longer sufficient to protect one's social status. Faced with perceived and real increases in socio-economic risk, the middle class might adopt a position that is more sympathetic with lower social layers, due to the fear that downward social mobility might also hit them in the future. ${ }^{7}$ Thus, the remainder of this article will first outline what is known about the socioeconomic profile of Pegida supporters, before comparing these findings with what is known about the centre ground of German politics.

To begin with, social science research had trouble catching up with the rapid emergence of Pegida. The first snapshot inquiry into the movement, based on a very small sample of interviewees, suggested that the typical Pegida supporter 'belongs to the middle class, is well-educated, employed, has a slightly-above average after-tax income in the context of Saxony, is 48 years old, male, not member of a religious denomination, not closely linked to a political party and is from Dresden or Saxony'. The same study suggested that general dissatisfaction with politics, criticism of media bias in reporting and concern about migrants and refugees (in this order) were the major mobilising factors. ${ }^{8}$

This first study was quickly criticised for possible failure to engage with more radical participants and for overemphasising the middle class character of the movement. Notably, the largest group of interviewees claimed to earn between 800 and 1500 euros after tax, which was above average in the context of Saxony, but below average in the context of Germany-pointing to a rather fragile lower middle-class position of many Pegida supporters.

Nevertheless, subsequent studies largely confirmed the initial picture. A significant share of Pegida supporters claimed to belong to the 'centre' on a left-right scale of political attitudes, although the majority located themselves on the right but not on the far right. At the same time, it was noticeable that Pegida supporters had above-average education (mostly in technical fields) and a higher than average tendency to participate in elections. A large number of interviewees stated to have voted AfD in the previous election, while the expressed level of support for the far-right NPD was not higher than in the general population. Thus, ongoing 
engagement with the political system-at least in terms of electoral participationcoexists with general lack of confidence in political institutions and the mainstream media. $^{9}$

Another study underlined that Pegida supporters fell into a majority of moderate rightists (about two thirds), while the rest belonged to the far right. The latter group tended to be younger and economically less established. In terms of party-political preference, the AfD enjoyed most support-being seen as not belonging to the established party system-followed by the CDU and NPD. A very small minority indicated support for the Left Party, while the moderate centre-left SPD and Green parties were practically absent from the Pegida milieu. Crucially, more than three quarters were disaffected from democracy as practised in the Federal Republic of Germany, and more than 90 per cent felt that they were not served by existing parties and politicians. ${ }^{10}$ One must conclude, therefore, that most Pegida supporters are not political outsiders but have some connections with the centre ground. However, they are very dissatisfied with the centre-right parties, namely the Merkel-led CDU.

\section{Can the centre hold?}

How, then, does the Pegida milieu relate to the centre ground of German politics? Here, two sociological lines of inquiry offer recent data to locate the Pegida phenomenon in its larger context, namely social milieu models and a recent study about Germany's political centre ground that was published briefly before the Pegida rallies took off.

In the former case, the long-established Delta and Sinus models (named after two companies who sell their respective models as a commercial service to facilitate consumer and political marketing) divide German society into around ten different milieus, organised according to socioeconomic, value and attitude cleavages. Both models share similarities with sociological concepts of inequality in other countries, such as the Goldthorpe class scheme in the case of Britain, but they claim to provide a more multi-dimensional approach that monitors objective and subjective factors.
The Delta and Sinus models are also known as 'potato graphics', since they both present the different social milieus organised in the form of overlapping circles. In the context of the Pegida movement, one might identify four milieus as analytically relevant. These are, in the case of the Delta model of 2011, selected here in order of relevance: (1) the 'bourgeois centre' (18 per cent, the largest milieu); (2) the 'traditionalists' (15 per cent); (3) the 'disadvantaged' (16 per cent); and (4) the 'conservatives' (4 per cent). Although the Delta model characterises the conservative milieu as part of the socioeconomic upper stratum of society-largely absent from the Pegida rallies - it might still serve as a reference point for the former three milieus.

Looking at these four milieus by way of the Delta description (and ignoring the other ones as less relevant in the Pegida context), one might identify at least a partial explanation for the 'centrist' features of Pegida. Namely, the 'bourgeois centre' favours 'the protection of the status quo' and 'aims to advance socially and professionally', while fearing increased job-related demands for flexibility and mobility and potential biographical disruptions due to economic restructuring. In the case of East Germany and Saxony, these issues certainly form the core of the life-biographical experience of most Pegida supporters. Their age profile is biased towards the generation over 40, which experienced the end of the GDR and the full-scale economic restructuring that followed.

In turn, the 'traditionalist' milieu suffers from rapid aging and decline in significance. This milieu is concerned with 'security and social order' and focuses mostly on the family and its immediate environment, while avoiding contact with new technology, lifestyle and value changes. Thus, traditionalists might be the core group of what West German sociologists have since the 1980s described as 'modernisation losers'. In the East German context of delayed transition towards a middle class-dominated societyin which a relative majority considered themselves to belong to the working class until recently - one must consider the traditionalist milieu to be still more significant than in West Germany. In addition, their 
worries about social change might also overlap with attitudes expressed by the 'bourgeois centre'.

As for the 'disadvantaged' milieu, 'strong fear and resentment' and the experience of 'low prospects for social advancement' triggered a 'resigned (...) basic attitude in combination with a retreat towards one's own social milieu'. It is noticeable that the disadvantaged milieu does not share the demographic decline of the traditionalist milieu. Instead, it remains fairly equally represented amongst all age groups in Germany and is the second largest of all milieus.

Finally, the 'conservative' milieu is elitist and consists mostly of the upper sections of the bourgeoisie. This milieu aspires to defend positions of cultural and socioeconomic leadership. Members are strongly focused on maintaining the institution of the family, considered to represent the principal agent of socialisation, and defend 'selfresponsibility' and 'normality'. They still consider their own resources to be sufficient to retain social distance from the popular strata. While this milieu is underdeveloped in East Germany, and has been absent from the Pegida rallies, it might still serve as a reference point for the other three milieus, notably the 'bourgeois centre', due to shared attitudes regarding society's 'natural' hierarchies.

Most significant, and worth quoting at length, is that the 'bourgeois centre' perceives social problems in Germany as follows: 'unemployment, crime, migration, real estate prices and rent levels, rising costs in the health service, protection of the welfare state, neglect of schools, pressure to acquire additional educational credentials to protect one's social position, concern over the integration of migrants and the perceived expansion of self-contained cultural minorities in some city quarters'. These issues result, according to the Delta researchers, in 'a slowly rising diffuse frustration about social conditions' and the feeling that 'one's own efforts to adapt are no longer rewarded'. ${ }^{11}$

In summary, concern about the future direction of German society is very common in the political centre ground; yet issues of concern vary and are difficult to unify for the purposes of political mobilisation. Thus, the Pegida milieu constitutes only one fac- tion within the larger bourgeois centre, which also includes progressive groups and concerns.

In order to further conceptualise the political attitude of Germany's bourgeois centre, one might also look secondly at recent focus group research. Here, a sociological study published directly pre-Pegida is relevant. It covered the political views of the 'upper' and 'lower' centre (the Mitte) in three West German cities over a number of years. The study highlighted general dissatisfaction with the political system in line with many features of the subsequent Pegida discourse; namely, interviewees considered the political system to be 'so corrupted and dusty that any kind of reform effort is hopeless'. Moreover, 'dishonesty, degeneration and lack of transparency were considered the central business terms of contemporary politics'. In addition, there was distrust of the mainstream media, held to be 'pressured by corporations in terms of advertisement revenue and belonging to a cartel of political and corporate interests'. The author summed up the pessimistic and negative attitude of the centre, suggesting that 'a great part of the centre is at present overwhelmed by contingency'. ${ }^{\prime 2}$

Ultimately, the study suggested that four ideal-types of dealing with contingency exist in the political centre, namely: (1) those searching for orientation to manage reality; (2) self-confident reducers of complexity; (3) ambitious artists of social opportunities; and (4) histrionic idealisers of the past. Ignoring details of this-perhaps not very convincing - effort to describe behavioural ideal types, the most significant result of this qualitative study was that three of the four types (2-4) are characterised by more or less aggressive hostility towards Germany's political class. The study also clarified, with reference to quantitative data quoted from other sources, that this general loss of confidence in the political system has only occurred since the 1990s. ${ }^{13}$

\section{Conclusion}

What lessons can be drawn from the Pegida case in the context of Germany's political culture? Four points deserve to be singled out by way of a conclusion. First, the general 
loss of confidence in the political system (Politikverdrossenheit) has become the dominant political attitude in the centre ground of German politics. This trend should be acknowledged as real rather than as a kind of tactical attitude of centrist citizens to place more pressure on the political class to improve its performance. In this context, the rapid decline in electoral participation in Germany-although not concentrated in the centre, but rather mostly amongst the disadvantaged groups - is alarming, as is the low confidence of the centre in its socio-economic stability and future prospects.

Second, the centre's distrust of the political system is due to structural factors that have been building up since the 1990s in the context of neoliberal economic restructuring. In particular, the decision of the then SPD and Green party government to severely retrench the welfare state (the so-called 'Hartz reforms' after 2002) produced large-scale demoralisation of the centre-left SPD's electoral base. This triggered in turn a permanent disengagement of disadvantaged milieus from the political system. Notably, the SPD lost half of its electoral support after the Hartz reforms and has never since been able to recover. Thus, the fact that SPD supporters have been largely absent from the Pegida rallies should not be considered a sign of strength of the centre left. On the contrary, former SPD supporters have by now been disengaged for so long that they no longer show up in opinion polls.

Third, the Pegida mobilisation raises the question to what extent 'modernisation losers' on the right of the political spectrum will permanently disengage from the centre right. It is conceivable that the CDU will now suffer losses among former core supporters. There are certainly many issues that could trigger a breakdown of the CDU's electoral coalition, such as the never-ending euro currency crisis or the poor management of refugee-related problems in Germany's complex and slow-moving federal system. In fact, the structural decline of the SPD might now be followed by a similar process in the CDU milieu. This tendency is more likely to persist since the centre right and the centre left-currently governing Germany in a grand coalition-are overwhelmingly concerned with competing for marginal voters in the centre while abandoning the more leftist and more rightist poles.

Fourth, the Pegida phenomenon of largely leaderless right-wing populism does point to a crisis of political representation. While Germany's party system appears more stable than is the case in other EU countries, this is largely due to the disengagement of large sections of the electorate and particularly of the disadvantaged groups. In order to make right-wing populism electorally viable, push and pull factors both need to be in place. In the German context, right-wing populism has suffered from organisational competition between moderate rightists and a far-right pole. In this context, the AfD party-the most recent effort to construct a 'moderate' party to the right of the CDU-has recently suffered a split between 'national liberals' and 'national conservatives'. Thus, the push factor of a right-wing populist movement in the streets is not necessarily going to directly spill over into the realm of parliamentary politics. Yet the Pegida surprise has shown that political stability in Germany should not be taken for granted. How the existing gap in political representation is going to be filled is anybody's guess.

\section{Notes}

1 No stated author, 'Demo gegen vermeintliche "Islamisierung"', Sächsische Zeitung, 27 October 2014; P. Becher, C. Begass and J. Kraft, Der Aufstand des Abendlandes, Köln, PapyRossa, 2015, pp. 8-9.

2 For basic facts on Pegida, see https://de.wiki pedia.org/wiki/Patriotische_Europ $\%$ C3\%A4er_ gegen_die_Islamisierung_des_Abendlandes (accessed 23 September 2015).

3 http:/ / www.i-finger.de/pegida-positionspapier. pdf (accessed 23 September 2015).

4 R. Dillmann, 'Stichwort Lügenpresse', Sozialistische Positionen, 1, 2015; Rosa-Luxemburg-Stiftung, 'Der NDR und die Lügenpresse', 1 July 2015, http://www.nrw.rosalux.de/news/41621/ der-ndr-und-die-luegenpresse.html (accessed 23 September 2015).

5 'PEGIDA-Zwischen Bürgerprotest und Radikalisierung', WDR TV documentary, reference 32:40 minutes, http://www.daserste.de/information/reportage-dokumentation/dokus/sendu ng/wdr/pegida-108.html (accessed 23 September 2015).

6 S. M. Lipset, Political Man. The Social Bases of Politics, New York, Doubleday, 1960, pp. 13449. 
7 S. Marg, Mitte in Deutschland. Zur Vermessung eines politischen Ortes, Bielefeld, Transcript Verlag (Studien des Göttinger Instituts für Demokratieforschung), 2014, pp. 167, 179, 201-3.

8 H. Vorländer, M. Herold and S. Schäller, Wer geht zu PEGIDA und warum?, Dresden, Zentrum für Verfassungs- und Demokratieforschung, 2015, pp. 43-73. The quote derives from the press release, 14 January 2015, https://tu-dresden.de/aktuelles/newsarchiv/2015/1/pegida_ pk (accessed 23 September 2015).

9 K. H. Reuband, 'Wer demonstriert in Dresden für Pegida? Ergebnisse empirischer Studien, methodische Grundlagen und offene Fragen', Mitteilungen des Instituts für deutsches und inter- nationales Parteienrecht der Universität Düsseldorf, 21, 2015, 133-43.

10 W. J. Patzelt and C. Eichardt, 'Drei Monate nach dem Knall: Was wurde aus Pegida?', Dresden, 21 May, pp. 76-9, https://tu-dresden.de/die_tu_dresden/fakultaeten/philosophi sche_fakultaet/ifpw/polsys/for/pegida/patzeltanalyse-pegida-mai-2015.pdf (accessed 23 September 2015).

11 All quotes translated by the author from $C$. Wippermann, Milieus in Bewegung: Werte, Sinn, Religion und Ästhetik in Deutschland, Würzburg, Echter, 2011, pp. 62-9.

12 Marg, Mitte in Deutschland, pp. 209, 212, 219, 240.

13 Ibid, pp. 244-50. 
Copyright of Political Quarterly is the property of Wiley-Blackwell and its content may not be copied or emailed to multiple sites or posted to a listserv without the copyright holder's express written permission. However, users may print, download, or email articles for individual use. 